\title{
¿6

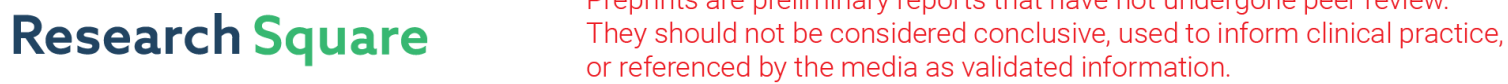 \\ Expression and Purification of the Extracellular Domain of Luteinizing Hormone Receptor From Ovis Aries Testicle
}

Jose Luis Villalpando-Aguilar

Instituto Tecnológico de Chiná: Instituto Tecnologico de China

Itzel López-Rosas

CONACYT: Consejo Nacional de Ciencia y Tecnologia

Arnulfo Montero-Pardo

Universidad Autónoma de Sinaloa: Universidad Autonoma de Sinaloa

Elisa Irene Azuara-Liceaga

Universidad Autonoma de la Ciudad de Mexico

Javier de Jesus Valencia-Méndez

Universidad Nacional Autonoma de Mexico Direccion General de Bibliotecas: Universidad Nacional

Autonoma de Mexico

Cynthia R. Trejo-Muñoz

Universidad Nacional Autonoma de Mexico Direccion General de Bibliotecas: Universidad Nacional

Autonoma de Mexico

William Rolando Cetzal-Ix

Instituto Tecnológico de Chiná: Instituto Tecnologico de China

Carlos Kubli-Garfias ( $\sim$ kubli@unam.mx)

UNAM Instituto de Investigaciones Biomedicas: Universidad Nacional Autonoma de Mexico Instituto de Investigaciones Biomedicas

\section{Short Report}

Keywords: Luteinizing hormone receptor, heterologous system expression, recombinant protein, GPCR, Ovis aries, Leydig cells

Posted Date: May 7th, 2021

DOI: https://doi.org/10.21203/rs.3.rs-428805/v1

License: (c) (1) This work is licensed under a Creative Commons Attribution 4.0 International License.

Read Full License 


\section{Abstract}

The luteinizing hormone receptor (LHR) is a glycoprotein member of the $\mathrm{G}$ protein-coupled receptor superfamily. Physiologically, this receptor participates in corpus luteum formation and ovulation in females. In males, it acts in testosterone synthesis and spermatogenesis and is involved in some fertility disorders. RNA was extracted from Ovis aries testicles, and the corresponding cDNA was synthesized to amplify the Ihrgene, termed Ihr-bed here, consisting of 762 bp that encodes 273 amino acids of the extracellular domain of LHR. Thus, the Ihr-bed was cloned into pJET1.2/blunt, subcloned into the pCOLD II expression vector and finally transformed into $E$. coli BL21 cells. Since the induced rLHR-Bed protein was found in the insoluble fraction, the purification protocol was modified as follows: induction at $25^{\circ} \mathrm{C}$, denaturing conditions (8 M UREA and $0.1 \%$ CHAPS) and refolding in the column to increase solubility. The rLHR-Bed expression was corroborated by western blotting and mass spectrometry (MS) analysis. This successful method to obtain the recombinant LHR extracellular domain yields $0.2 \mathrm{mg} / \mathrm{L}$ of the protein with approximately $90 \%$ purity from a single chromatographic purification step. The present approach demonstrates the feasibility of obtaining large quantities of rLHR-Bed. This might be useful to accomplish future studies regarding the structure and functional analysis of the binding interplay with its ligand luteinizing hormone and its isoforms. Additionally, this biotechnological strategy might be used to improve and to develop new drugs for the treatment of reproductive disorders and might also be applied to species reproduction in the livestock industry.

\section{Introduction}

Luteinizing hormone receptor (LHR) was expressed for the first time from the rat ovary [1] and was categorized as an "unusual" member of the G protein-coupled receptor family. In fact, LHR belongs to the G-protein coupled receptor (GPCR) superfamily, and its ligand is luteinizing hormone (LH), a glycoprotein secreted by the anterior hypophysis. Structurally, GPCRs belong to seven transmembrane domain receptors with extracellular $(\mathrm{NH} 2)$ and intracellular $(\mathrm{COOH})$ termini. LHR is located in the luteal theca and follicular granulosa cells of the ovary, while in the testis, it is located mostly in the Leydig cells, which secrete testosterone. Interestingly, LHR is also expressed in the placenta [2]. Biologically, LHR is involved in crucial reproductive processes, including oocyte maturation, ovulation, and estradiol synthesis in females. In males, it participates in testosterone synthesis and sex differentiation, among others [3].

The receptor binds its ligand $\mathrm{LH}$ through a unique large extracellular domain conformed in the sheep by 341 amino acids (a.a). This domain is encoded in the Ihr gene, exons $1-10$, which has a signal peptide and a leucine-rich repeat (LRR) region and is flanked by cysteine-rich regions [3]. In addition, LHR binds human chorionic gonadotropin (hCG), a placental hormone essential in progesterone synthesis during pregnancy. In the testis, LHR is activated by LH, also called interstitial cell-stimulating hormone, initiating the transduction process via activating cAMP, and the reaction pathways to synthesize testosterone by Leydig cells [4]. The second large domain of LHR, encoded into the Ihrgene, comprises the long eleventh exon, which is distinctive of the GPCR structure, formed by seven transmembrane a-helices and a cytoplasmic tail corresponding to the carboxy-terminus [5]. 
As occurs with most GPCRs, the tertiary structure of the LHR is not available. However, LHR has been studied and expressed in several ways, such as human embryonic kidney cells [5] and mouse reproductive tissues [6]. Moreover, LHR has been expressed in baculovirus-infected insect cells [6, 7]. The extracellular domain of LHR in rats and humans has been expressed in E. coli [8, 9]. Notably, the X-ray structure of the extracellular domain of follicle-stimulating hormone receptor (FSHR) complexed with follicle-stimulating hormone (FSH), the analogous hormone of $\mathrm{LH}$, has been solved [10]. These data have been very useful to compare both receptors FSHR and LHR [11]. Analyzing the sheep receptor, the whole LHR sequence shows $51 \%$ similarity in comparison with FSHR. However, considering only the extracellular domain in both receptors, the sequence similarity decreases to $40.5 \%$, not including the initial signal peptide sequence. Certainly, those conserved sequences are valuable data but insufficient to realize solid molecular modeling and structural biology studies, particularly to unveil the extent of those a.a. interacting with $\mathrm{LH}$.

Indeed, complementary studies are needed to pursue the tertiary LHR structure. This knowledge may be useful to understand the hormone-receptor interactive mechanism, its physiological implications and possible pharmacological applications. Since our group has been interested in the endocrinology and biology of reproduction, particularly LH, in the sheep [12] and goat estrous cycle [13], we decided to obtain the extracellular domain of LHR in a protein expression heterologous system as an initial step for future experiments directed to solve the final LHR structure.

\section{Materials And Methods}

\section{RT-PCR}

Total RNA from $250 \mathrm{mg}$ of testicular tissue was extracted using the TRIzol method. To obtain Ovis aries cDNA, $1 \mu \mathrm{g}$ of total RNA was treated with the Superscript II reverse transcriptase kit and oligo $\mathrm{dT}_{18}$ primer $(10 \mathrm{pmol} / \mu \mathrm{l})$. The extracellular domain of LHR, as stated before, was termed Ihr-bed. Then, Ihr-bed was amplified from the synthesized cDNA using the primers 5-

CGAATTCCATATGTCACTCACCTACCTCCCTATCAA (forward) and 5-

CCGCTCGAGAAGTGTTTCATTATTTGGTCTCCTTGC-3 (reverse) with the restriction sites (underlined) targeted by the enzymes Ndel and Xhol, respectively. The PCR conditions were $94^{\circ} \mathrm{C}$ for $5 \mathrm{~min} ; 94^{\circ} \mathrm{C}$ for 1 min; $60^{\circ} \mathrm{C}$ for $1 \mathrm{~min}$; and $72^{\circ} \mathrm{C}$ for $1 \mathrm{~min}$, allowing $35 \mathrm{cycles}$ and a final stage of $72^{\circ} \mathrm{C}$ for $7 \mathrm{~min}$.

\section{Cloning, Expression and Purification of the rLHR-Bed}

The obtained 762 bp amplicon was cloned into pJET1.2/blunt with the CloneJET PCR cloning Kit, subcloned into the pCOLD II vector and transformed into BL21 (DE3) chemically competent cells. The clone that expressed the rLHR-Bed (recombinant extracellular domain luteinizing hormone receptor) fused with a histidine tag was incubated in a bath at $25^{\circ} \mathrm{C}$ for 30 minutes. After that, for induction, IPTG (1 mM) was added and incubated with agitation for 18 hours at $25^{\circ} \mathrm{C}$ as outlined in the Cold Shock Expression System Manual, suggesting a $25^{\circ} \mathrm{C}$ modification protocol [14]. The protein was purified using a Ni-NTA 
column following the refolding protocol of the manufacturer in AKTA Prime FPLC, working under denaturing conditions with buffer modifications as follows: A) Solubilization buffer: $20 \mathrm{mM}$ Tris; $0.5 \mathrm{M}$ $\mathrm{NaCl} ; 5 \mathrm{mM}$ imidazole; $8 \mathrm{M}$ UREA and 0.1\% CHAPS. B) Refolding buffer: $20 \mathrm{mM}$ Tris; $0.5 \mathrm{M} \mathrm{NaCl} ; 5 \mathrm{mM}$ imidazole and $0.1 \%$ CHAPS. Finally, C) Elution buffer: $20 \mathrm{mM}$ Tris; $0.5 \mathrm{M} \mathrm{NaCl} ; 250 \mathrm{mM}$ imidazole and $0.1 \%$ CHAPS. The degree of purity of the isolated sample was evaluated by electrophoresis in a $12 \%$ SDSPAGE gel stained with Coomassie brilliant blue.

rLHR-Bed identification through WB and MS.

Data on rLHR-Bed detection by antibody anti-His monoclonal and mass spectrometric (MS) are found in Supplementary file.

\section{Computational Methods}

The computational assessment was performed using the genome assembly Oar_rambouillet_v1.0 of the sheep (Ovis aries), along with the NC_040254.1 locus to disclose the Ihr genomic characteristics. The final protein analyses were carried out with the Conserved Domain Database using the Bath-CD-Search [15], using the TMHMM Server v. 2.0 [16] and the Protein Secondary Structure Prediction Server [17].

\section{Results And Discussion}

The Ovis aries Ihrgene was the aim of the present work. In sheep, this gene is composed of eleven exons and is located on chromosome 3. LH, along with FSH and TSH receptors, forms a subfamily characterized by a large ectodomain bearing a leucine-rich region and glycosylated $\mathrm{N}$-terminus, which actually is the binding site of their respective hormones. For this reason, through a heterologous system, the recombinant protein of the LHR external domain was expressed and termed $/ \mathrm{hr}$-bed. The starting point was the Ovis aries Oar_v4.0 genome assembly with the accession ID: GCF_000298735.2 and locus: NC_040254.1, belonging to the Ihrgene, which has a size of 1,965 bp (Fig. 1a1). Related to the /hrgene, a downstream genome sequence of $1,308 \mathrm{bp}$ is located at the GTF2A1L gene, while the upstream genome sequence regarding the Ihr gene has $1,484 \mathrm{bp}$ and is found at the LOC114113602 gene (Fig. 1a1). The expressed LHR transcription has a mRNA of 1,965 bp comprising 11 exons. The extracellular region is encoded by exons 1-10 while the seven-transmembrane domain is encoded by exon eleven (Fig. 1a2).

The computational analysis of the large N-terminal extracellular domain, including the LRR (Fig. 1a2) related to LHR-LH binding and the transmembrane region, shows a complete protein composed of 654 a.a. However, in the present work, the amplified Ihr-bed mRNA from 0 . aries testis included only the region between exons 2 and 10, that is, 762 bp encoding only 273 a.a (Fig. 1a2). Interestingly, the LHR gene has already been reported to be expressed in rodent Leydig cells [18].

One important goal was to reach a reliable production of recombinant Ihr-bed. Therefore, cold shock expression technology was applied; that is, cloning and subcloning the /hr-bed gene ligated to the pCOLD II vector expression. After that, the positive selection cloning vector pJET1-2-blunt-Ihr-bed was subcloned 
for expression and efficient recovery. Consequently, the DNA insert of $762 \mathrm{bp}$ cloned from pJET1.2/BLUNT (Fig. 1b) was ligated into the pCOLD II vector. The subcloning process included both Ndel and Xhol digestion enzymes.

Special care was taken for the correct size and alignment of the pCOLDII vector as well as the insert Ihrbed gene in gel agarose (Fig. 1c). Regarding this gel, lane 2 shows the corresponding insert to the Ihr-bed with 762 bp size, and the linearized pCOLD II shows a size of 4392 bp, in lane 3 (Fig. 1c). The results of cloning and subcloning are depicted in Fig. $1 \mathrm{~b}$ and c. It is important to remark that the pCOLDII vector is suitable for application in proteins intrinsically difficult to express, which require low temperature $\left(15^{\circ} \mathrm{C}\right)$ and show a slow translation process. Additionally, it ensures improved folding and stability of the recombinant protein during its expression, and, very importantly, produces high amounts of protein in $E$. coli [19].

The induction experiment yielded several clones resulting from the pCOLDII-Ihr-bed construction, which actually were transformed into BL21 strain bacteria. Thus, the experiment to induce the recombinant protein of the extracellular domain of LHR Ovis aries (rLHR-Bed) was designed as follows: BL21 cells transformed with pCOLDII-empty were labeled negative induction, while clones 2 and 4 were positive, resulting in the transformed pCOLDII-Ihr-bed construction.

The extent of protein expression was evaluated through SDS-PAGE profiles. Likewise, recombinant protein with a histidine tag of $50 \mathrm{kDa}$ was added as a WB positive control (Fig. 2a, lane 10). In the case of BL21 clone 2, no expression of the recombinant protein was found (Fig. 2a, lanes 3 and 5). In contrast, a band of $\sim 28 \mathrm{kDa}$ corresponding to the induction elicited by clone 4 was observed (Fig. 2a, lane 7). To corroborate that the band located between 25 and $37 \mathrm{kDa}$ was actually the rLHR-Bed, a WB analysis was applied using an anti-His tag antibody and mediated with a twin gel corresponding to the protein profile of the induction experiment (Fig. 2b).

Unexpectedly, the expression study carried out under standard conditions using BL21 transformed with constructed pCOLDII-Ihr-bed growing at $180 \mathrm{rpm} / 15^{\circ} \mathrm{C} / 18 \mathrm{~h}$ failed, somewhat yielding low expression of rLHR-Bed (data not shown). Therefore, a modified procedure was implemented according to Spadiut et al. [14], raising the temperature from $15^{\circ} \mathrm{C}$ to $25^{\circ} \mathrm{C}$ and performing a preinduction course, resulting in optimum induction of $24 \mathrm{U} / \mathrm{L}$ recombinant protein. Accordingly, applying those modifications successfully induced rLHR-Bed, showing that the pCOLDII system is stable and functional at $25^{\circ} \mathrm{C}[14]$.

In addition, the rLHR-Bed induction elicited by clone 4 was submitted to solubility evaluation. The resulting SDS-PAGE showed a marked band in the insoluble fraction, especially in the range between 25 and $37 \mathrm{kDa}$, while the soluble fraction in that range showed lower intensity (Fig. 2c). The rLHR-Bed was clearly confirmed in the insoluble fraction by the WB experiment (Fig. 2c, lane 5). However, the solubility analyses of rLHR-BED showed that the expressed protein yielded inclusion bodies, compelling us to implement a column protocol. That is, a denaturation-refolding scheme to obtain the recombinant protein soluble to finish the rLHR-Bed purification. In this way, the denaturing condition was achieved by modifying the solubility buffer to $0.1 \%$ CHAPS, which is considered the minimal micellar concentration to 
improve the solubility of recombinant proteins [20]. The solubility results, including the complete profile of purification, are shown by SDS-PAGE (Fig. 2d). Interestingly, in the case of insoluble protein aggregates forming inclusion bodies, the protein conserves its native-state secondary structure [21]. Thus, as anticipated, the expressed and purified protein was actually rLHR-Bed and was fully validated by two reliable techniques: WB mediated with anti-histidine monoclonal antibody and mass spectrometric (MS) analysis (Supplementary file). These final results corroborated that the induced protein indeed corresponds to the rLHR-Bed of $O$. aries .

On the other hand, two vials containing the purified recombinant protein with a performance of $0.25 \mathrm{mg} / \mathrm{L}$ were submitted to acquire an electrophoretic profile, and the band was cut and sent for MS identification to the proteomic unit of the Instituto de Biotecnología-UNAM, México. Seven peptides were identified corresponding to $100 \%$ probability to the Lutropin-choriogonadotropin-hormone receptor OS=Ovis aries, according to the UniProt source database (Table 1). Clearly, the spectrum mass/charge (M/Z) vs. relative intensity corresponding to each peptide showed the sequenced peptide, protein identification probability, percent of the best peptide and spectrum M/Z (Table 1).

LHR has been expressed in different models not exempt from drawbacks; for instance, in human embryonic kidney cells, the expressed extracellular domain shows high affinity to hCG but remains trapped within the cells [5]. Similarly, LHR expressed in baculovirus-infected insect cells is inactive and remains trapped in aggregate pools [6]. The rat extracellular domain of LHR has been expressed in E. coli, with high binding affinity for hCG; however, proper folding is achieved only after laborious refolding in vitro [8]. Additionally, in E. coli, the extracellular domain of the human receptor expressed in a chimeric fusion model, including thioredoxin reductase and glutathione reductase genes in the cloning plasmid vector, maintained the disulfide bonds of the expressed LHR extracellular domain and confirmed that regardless of the lack of glycans, the truncated receptor may show high affinity to hCG, similar to the native receptor [9]. Nevertheless, this elegant design is still quite elaborated. More complex chimeric expression of the extracellular domain of the $\mathrm{LH}$ receptor has been elaborated but rather more expensive, as has been reported in CD8 lymphocyte membranes [22]. In the present work, certain advantages of the improved technique were achieved; for instance, disulfide bonds were retained since $\beta$-mercaptoethanol was not used. Likewise, dialysis was avoided, allowing easy refolding of the protein in the repurification procedure, leaving the receptor in a friendly refolding buffer ready for future crystallization.

In addition to crystallization as well as molecular properties and physicochemical studies, many possibilities arise mostly in the field of biology of reproduction and the livestock industry. In our group, we are willing to test the binding of LH isoforms in the expressed extracellular LHR motive, since working with LH isoforms previously, some differences have been observed in cAMP and vascular endothelial growth factor production [12].

Briefly, in the present work, the extracellular domain of LHR was expressed successfully based on a reliable and minimal effort molecular biology strategy. The protein rLHR-bed from $O$ aries, expressed from the Ihr-bed gene, was obtained from testicular Leydig cells. BL21 competent cells and the pCOLDII vector 
were selected to amplify the gene. Thus, based on the current literature, we proposed the strategy of induction-solubilization-refolding and purification in a raw sample. The procedure was $\beta$ mercaptoethanol-free, and dialysis was omitted. In this way, the recombinant protein was expressed in significant amounts and ready for subsequent structural analyses. The results suggest that this strategic pathway could be applied to express almost any membrane protein effortlessly.

\section{Abbreviations}

CID: Collision-induced dissociation

ESI: Nano-electrospray ionization source

FDR: False Discovery Rate

HCD: high energy collision dissociation

hCG: human chorionic gonadotropin

LC-MS/MS: Liquid Chromatography with tandem mass spectrometry

LHCGR: Lutropin-choriogonadotropin hormone receptor

(m/z): mass/charge

rLHR-Bed: recombinant Luteinizing Hormone Receptor-Bed

\section{Declarations}

\section{Funding}

This work was supported by Dr. Carlos Kubli-Garfias and the Colegio de Postgraduados Campus Campeche, México.

\section{Conflicts of interest/Competing interests}

The authors declare that they have no conflict of interests.

\section{Authors' contributions}

All authors contributed to the study conception and design. Material preparation, data collection and analysis were performed by [José Luis Villalpando-Aguilar] and [Itzel López-Rosas]. The first draft of the manuscript was written by [José Luis Villalpando-Aguilar] and [Itzel López-Rosas] and all authors commented on previous versions of the manuscript. All authors read and approved the final manuscript. These authors contributed equally [José Luis Villalpando-Aguilar] and [Itzel López-Rosas]. 


\section{Consent for publication}

The authors give consent for publication of this work.

\section{Acknowledgments}

We thank Dr. Cesar V. F. Batista, Head of the Laboratorio Universitario de Proteómica (LUP), Instituto de Biotecnología-UNAM for helping us to the rLHR-Bed identification. We also acknowledge Colegio de Postgraduados Campus Campeche for supporting the research with some chemical substances.

\section{References}

1. McFarland KC, Sprengel R, Phillips HS, et al (1989) Lutropin-choriogonadotropin receptor: an unusual member of the $\mathrm{G}$ protein-coupled receptor family. Science 245:494-499. https://doi.org/10.1126/science.2502842.

2. Bukovsky A, Indrapichate K, Fujiwara $\mathrm{H}$, et al (2003) Multiple luteinizing hormone receptor (LHR) protein variants, interspecies reactivity of anti-LHR mAb clone 3B5, subcellular localization of LHR in human placenta, pelvic floor and brain, and possible role for LHR in the development of abnormal pregnancy, pelvic floor disorders and Alzheimer's disease. Reprod Biol Endocrinol 1:46. https://doi.org/10.1186/1477-7827-1-46.

3. Puett D, Angelova K, da Costa MR, et al (2010) The luteinizing hormone receptor: Insights into structure-function relationships and hormone-receptor-mediated changes in gene expression in ovarian cancer cells. Mol Cell Endocrinol 329:47-55. https://doi.org/10.1016/j.mce.2010.04.025.

4. Dufau ML (1998) The Luteinizing Hormone Receptor. Annu Rev Physiol 60:461-496. https://doi.org/10.1146/annurev.physiol.60.1.461.

5. Xie YB, Wang H, Segaloff DL (1990) Extracellular domain of lutropin/choriogonadotropin receptor expressed in transfected cells binds choriogonadotropin with high affinity. J Biol Chem 265:2141121414.https://doi.org/10.1016/S0021-9258(18)45750-X.

6. Pajot-Augy E, Couture L, Bozon V, et al (1995) High-level expression of recombinant porcine LH receptor in baculovirus-infected insect cells or caterpillars. J Mol Endocrinol 14:51-66. https://doi.org/10.1677/jme.0.0140051.

7. Narayan P, Gray J, Puett D (1996) Expression of functional lutropin/choriogonadotropin receptor in the baculovirus system. Mol Cell Endocrinol 117:95-100. https://doi.org/10.1016/03037207(95)03735-7.

8. Chen W, Bahl OP (1993) High expression of the hormone binding active extracellular domain (1-294) of rat lutropin receptor in Escherichia coli. Mol Cell Endocrinol 91:35-41. https://doi.org/10.1016/0303-7207(93)90252-F.

9. Lobel LI, Pollak S, Klein J, Lustbader JW (2001) High-level bacterial expression of a natively folded, soluble extracellular domain fusion protein of the human luteinizing hormone/chorionic 
gonadotropin receptor in the cytoplasm of Escherichia coli. Endocrine 14:205-212.

https://doi.org/10.1385/END0:14:2:205.

10. Jiang X, Dias JA, He X (2014) Structural biology of glycoprotein hormones and their receptors: Insights to signaling. Mol Cell Endocrinol 382:424-451. https://doi.org/10.1016/j.mce.2013.08.021.

11. Ulloa-Aguirre A, Zariñán T, Jardón-Valadez E, et al (2018) Structure-Function Relationships of the Follicle-Stimulating Hormone Receptor. Front Endocrinol 9:707.

https://doi.org/10.3389/fendo.2018.00707.

12. Montero-Pardo A, Diaz D, Olivares A, et al (2015) Effect of ovine luteinizing hormone (oLH) charge isoforms on VEGF and cAMP production. Anim Reprod Sci 163:35-47.

https://doi.org/10.1016/j.anireprosci.2015.09.015.

13. Martínez-Álvarez LE, Hernández-Cerón J, González-Padilla E, et al (2007) Serum LH peak and ovulation following synchronized estrus in goats. Small Rumin Res 69:124-128. https://doi.org/10.1016/j.smallrumres.2005.12.024.

14. Spadiut O, Posch G, Ludwig R, et al (2010) Evaluation of different expression systems for the heterologous expression of pyranose 2-oxidase from Trametes multicolor in E. coli. Microb Cell Factories 9:14. https://doi.org/10.1186/1475-2859-9-14.

15. Lu S, Wang J, Chitsaz F, et al (2020) CDD/SPARCLE: the conserved domain database in 2020. Nucleic Acids Res 48:D265-D268. https://doi.org/10.1093/nar/gkz991.

16. Krogh A, Larsson B, von Heijne G, Sonnhammer ELL (2001) Predicting transmembrane protein topology with a hidden markov model: application to complete genomes11Edited by F. Cohen. J Mol Biol 305:567-580. https://doi.org/10.1006/jmbi.2000.4315.

17. Drozdetskiy A, Cole C, Procter J, Barton GJ (2015) JPred4: a protein secondary structure prediction server. Nucleic Acids Res 43:W389-W394. https://doi.org/10.1093/nar/gkv332.

18. Apaja PM, Aatsinki JT, Rajaniemi HJ, Petäjä-Repo UE (2005) Expression of the Mature Luteinizing Hormone Receptor in Rodent Urogenital and Adrenal Tissues Is Developmentally Regulated at a Posttranslational Level. Endocrinology. 146:3224-3232. https://doi.org/10.1210/en.2005-0073.

19. Qing G, Ma L-C, Khorchid A, et al (2004) Cold-shock induced high-yield protein production in Escherichia coli. Nat Biotechnol 22:877-882. https://doi.org/10.1038/nbt984.

20. Seddon AM, Curnow P, Booth PJ (2004) Membrane proteins, lipids and detergents: not just a soap opera. Lipid-Protein Interact 1666:105-117. https://doi.org/10.1016/j.bbamem.2004.04.011

21. Ventura S, Villaverde A (2006) Protein quality in bacterial inclusion bodies. Trends Biotechnol 24:179-185. https://doi.org/10.1016/j.tibtech.2006.02.007.

22. Osuga Y, Kudo M, Kaipia A, et al (1997) Derivation of Functional Antagonists Using N-Terminal Extracellular Domain of Gonadotropin and Thyrotropin Receptors. Mol Endocrinol 11:1659-1668. https://doi.org/10.1210/mend.11.11.0005.

\section{Table}


Due to technical limitations, table 1 PDF is only available as a download in the Supplemental Files section.

\section{Figures}

a
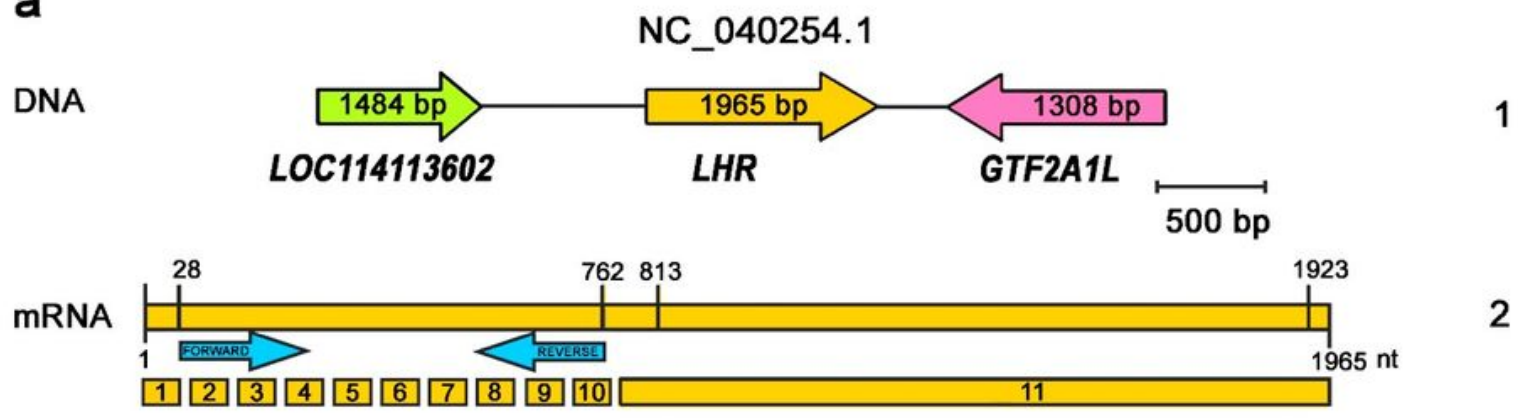

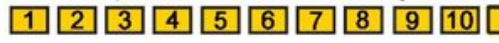

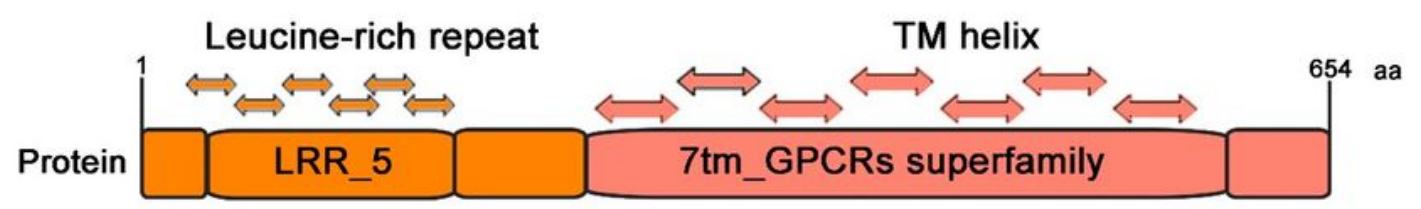

$\Leftrightarrow$ Leucine-rich repeat

$\longleftrightarrow$ TM helix

b
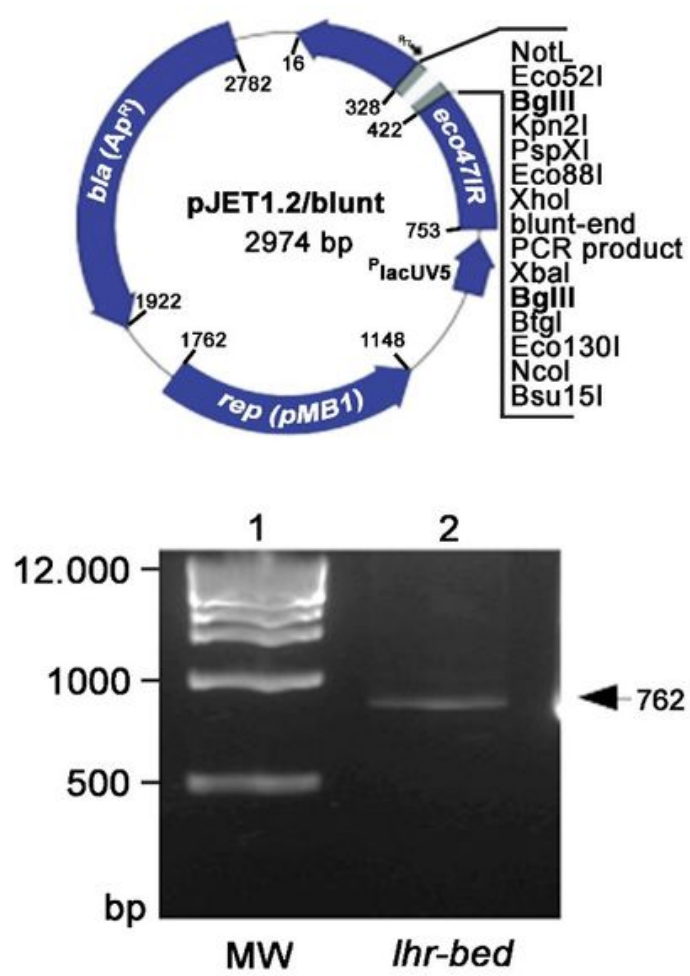

C

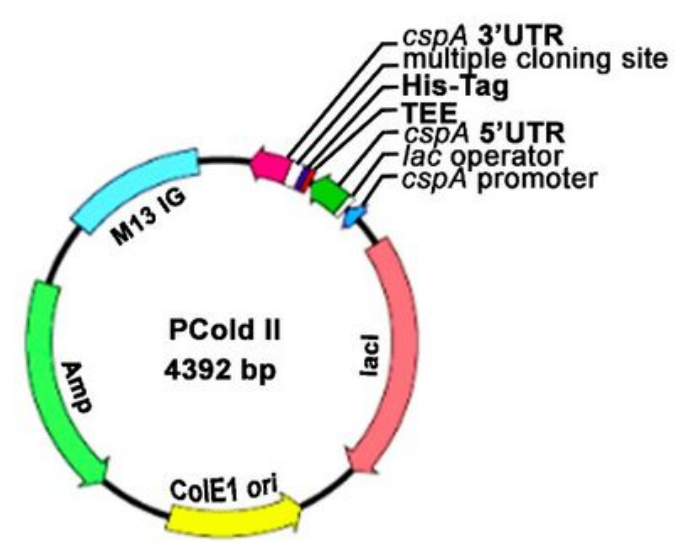

1

2

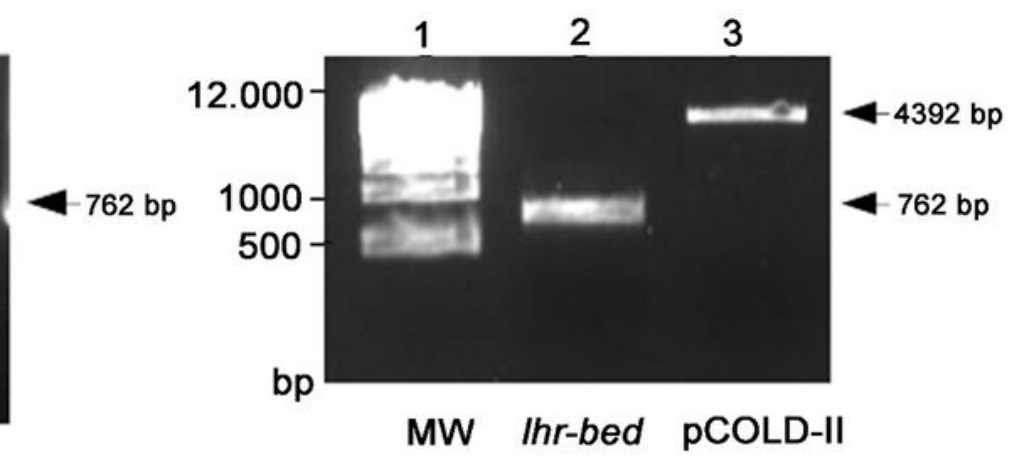

Figure 1 
Genomic Location of LHR gene in Ovis aries. a1) Depicts the LHR gene comprising 1965 bp length. The upstream and downstream LHR genes occupy the LOC114113602 and GTF2A1L gene loci encoded by $1484 \mathrm{bp}$ and $1308 \mathrm{bp}$, respectively. a2) Eleven exons encompass the LHR mRNA. Exons 1 to 10 encode the extracellular domain while the 7TMD and the carboxy terminal are encoded by the long exon 11. a3) LHR arrangement of LHR predicted according to NCBI Batch CD-Search, showing 2 domains: a leucinerich region (LRR) and seven transmembrane helices characteristic of the GPCR superfamily. b) Cloning Ihr-bed gene. Characteristics of the store plasmid pJET.2/blunt cloning vector for lhr-bed are shown. Likewise, the amplicon (insert) with a size of 762 bp corresponding to the lhr-bed is in lane 2. c) Bands of the expressed vector pCOLD II (lane 3 ) and the insert of 762 bp yielding the pCOLD II-lhr-bed as product expression after digestion by Ndel and Xhol enzymes and ligation with T4 ligase (lane 2). The MW of the DNA marker $(1 \mathrm{~kb})$ is shown in $\mathrm{b}$ and $\mathrm{c}$, lane 1.

a

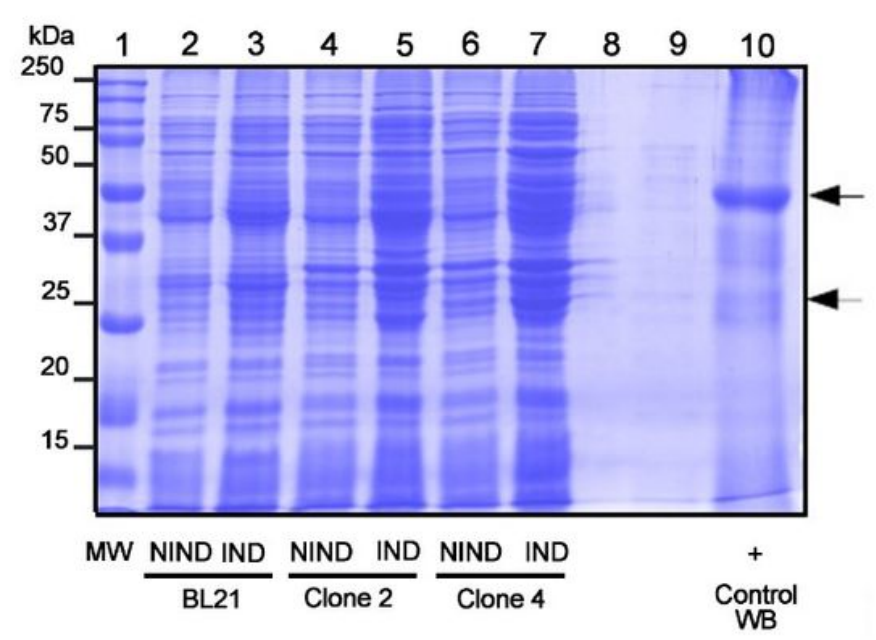

c

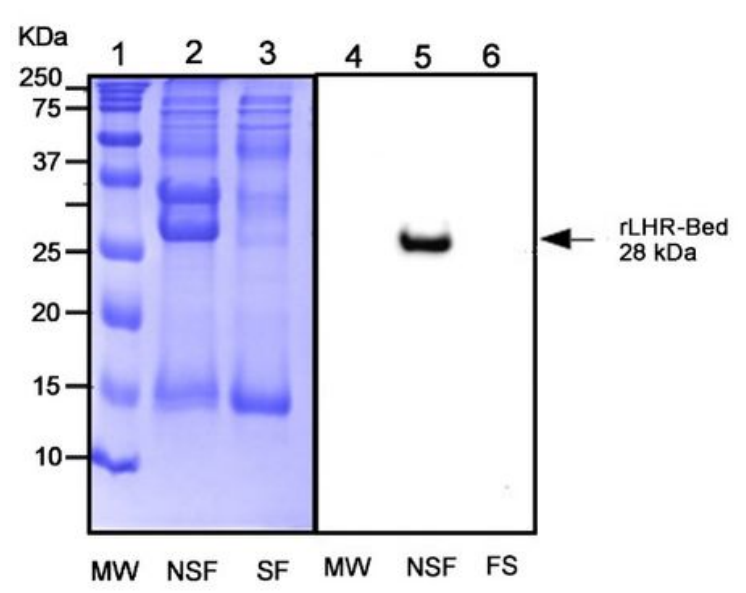

b

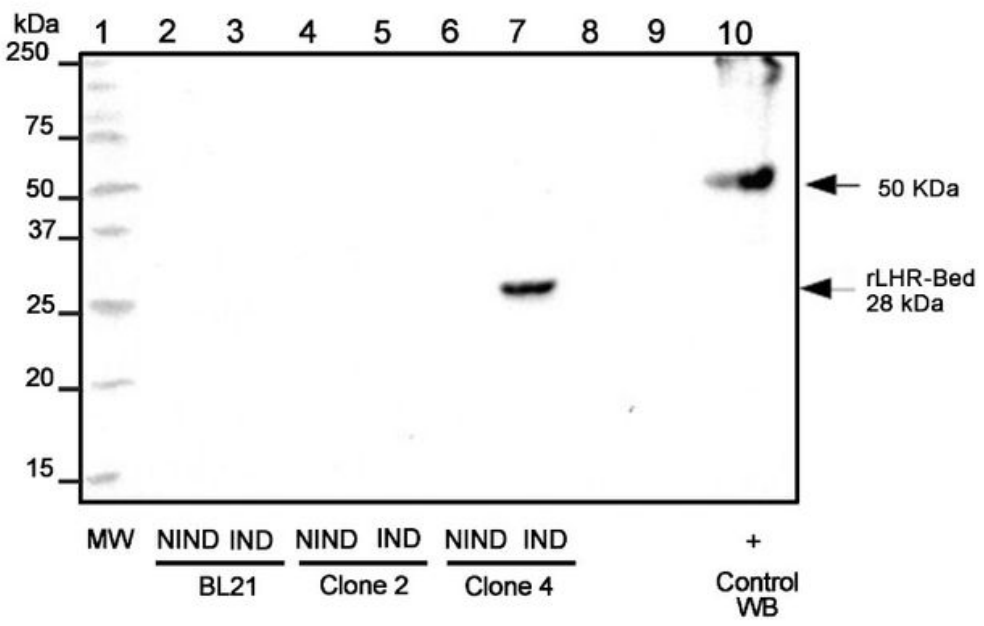

d

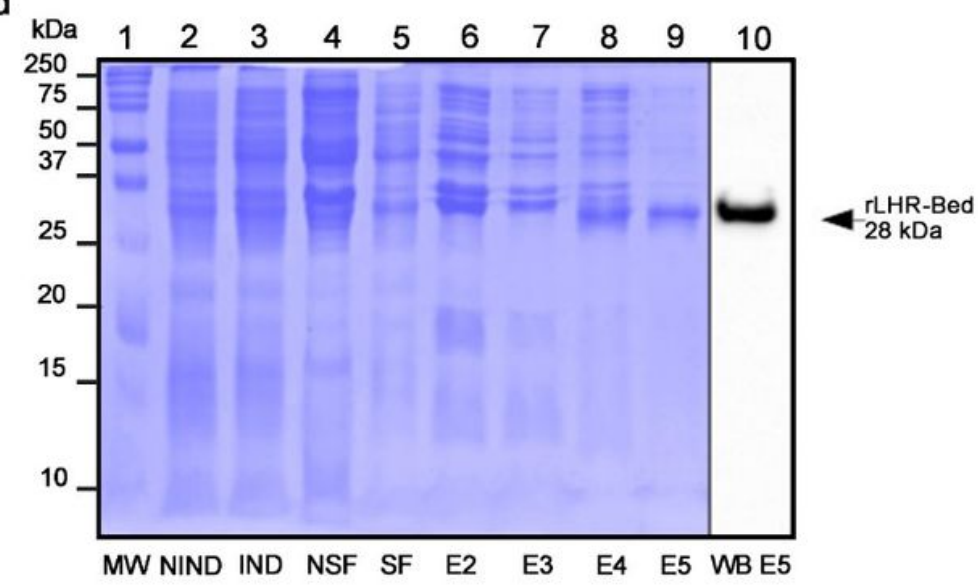

\section{Figure 2}

rLHR-Bed induction-solubilization-refolding -purification profile. a) Molecular Weight (MW) lane 1, Noninduction (NIND) and Induction (IND) for: BL21 cells without transformation, Clone 2, and Clone 4, See 
lanes 2 to 7. b) Western blot (WB) shows the corresponding gel of the SDS-PAGE rLHR-Bed profile showing the detection signal between 25 and $37 \mathrm{kDa}$, this expression is coincident with rLHR-Bed (lane 7). The WB control was a $50 \mathrm{kDa}$ protein with tag histidines and it is shown in lane 10. Arrows show the control protein and the recombinant expression protein of $28 \mathrm{kDa}$. c) Solubility profile test of rLHR-Bed shows: MW lane 1, non-soluble fraction (NSF) and soluble fraction (SF) lanes 2 and 3, arrow marks the rLHR-Bed. WB from a gel SDS-PAGE of the rLHR-Bed solubility profile. MW Lane 4, NSF and SF lanes 5, 6 respectively. Detection of rLHR-Bed is observed in the NSF at $28 \mathrm{kDa}$ (lane 5). (d) Complete profile of rLHR-Bed purification and its WB detection. MW lane 1, NIND and IND samples, are lanes 2, 3. NSF and SF lanes 4 and 5 and elution 2 to elution 5 lanes 6 to 9 . Lane 10 shows the WB detection elution 5.

\section{Supplementary Files}

This is a list of supplementary files associated with this preprint. Click to download.

- SupplementaryInformationKubliGarfiaset.al.pdf

- GRAPHICALABSTRACKubliGarfiaset.al.tif

- TABLE1.MASSSPECTROMETRICKubliGarfiaset.al.pdf 